Kong. Res. J. 1(1) : 108-110, 2014

Kongunadu Arts and Science College, Coimbatore

\title{
ASYMBIOTIC SEED GERMINATION AND SYNTHETIC SEED PREPARATION OF VANDA TESTACEA (LINDL.) RCHB.F .
}

\author{
Thirugnanasampandan, R*., S.Monisha, M.Gogul Ramnath and G.Ramya \\ PG and Research Department of Biotechnology, Kongunadu Arts and Science College, Coimbatore. \\ *E.mail: rtsampandan@yahoo.com
}

\begin{abstract}
A protocol for asymbiotic seed germination and synthetic seed preparation of Vanda testacea(Lindl.) Rchb.f. from mature pods was developed. Seed germination was successfully established on half strength $\mathrm{B}_{5}$ (Gamborg's medium) supplemented with $1.0 \mathrm{mg} / \mathrm{L} \mathrm{GA}_{3}$. Protocorm like bodies (PLB's) were formed after 90 days of culture and further artificial seed preparation of matured protocorm was successful using $5 \%$ sodium alginate and $100 \mathrm{mM}$ calcium chloride. The beads were inoculated on half strength $\mathrm{B}_{5}$ medium supplemented with $1.0 \mathrm{mg} / \mathrm{L} \mathrm{GA}_{3}$.
\end{abstract}

Keyword: Vanda testacea, seed germination, artificial seed preparation, Protocorm.

\section{INTRODUCTION}

Vanda testacea (Lindl.) Rchb.f. is a species of orchid occurring from the Indian subcontinent to Indochina at the elevations of 500 to 2000 meters. It is an epiphytic perennial. In India orchids form $9 \%$ of flora and are the largest family among higher plants. It is estimated that about 1,300 species (140 genera) of orchids are found in our country with Himalayas as their main home and others scattered in eastern and Western Ghats. Vanda testacea (Lindl.) Rchb.f. has medicinal properties in sciatic nerve transaction (axotomy) induced peripheral neuropathy in rats (Santh Rani Thaakur and Swapna Pokkula, 2013). Root used to treat nervous disorders, piles, and inflammations as well as a potential anticancerous drug. Leaves, flowers in powder form are used as herbal medicines to cure rheumatism and bronchitis (Chauhan , 1990) . Asymbiotic seed germination by in vitro culture, which was first introduced and it has revolutionized the concept of orchid cultivation. Soumi Neha (2013).

Vanda testacea (Lindl.) Rchb.f. has a low rate of multiplication under natural/greenhouse conditions and like other monopodial orchids, surviv al of mother plant is not conducive to a shoot tip / meristem based micropropagation system. It is thus necessary to device a rapid and efficient micropropagation. Orchid seeds became necessary for future sustainable harvesting system and maintaining orchid species to prevent from genetic erosion. Hence the present study was focused on seed germination and artificial seed preparation of Vanda testacea using matured pods.

\section{MATERIALS AND METHODS}

\subsection{Source of plant material}

The mature pods of Vanda testacea(Lindl) Rchb.f. was provided by Dr.T.Muthukumar, Department of Botany, Bharathiar University, Coimbatore.

\subsection{Explant selection and mode of sterilization}

Collected mature pods were surface sterilized by immersing in $70 \%$ ethanol for 10 sec. The sterilized pods were then washed 4-5 times with sterile double distilled water. Further capsules were cut longitudinally with a sterile scalpel and the seeds were inoculated on to half strength $B_{5}$ medium.

\subsection{Method of media preparation}

Half $\mathrm{B}_{5}$ (Gamborg's) medium was employed in the present study and the composition of the medium is given in Table-1. For media preparation, only analytical reagents of "Hi-media" chemicals and Borosil glassware's were used. Double distilled water was used for media preparation. Stock solutions were prepared separately for macronutrients, micronutrients, iron, potassium iodide and vitamins. All the chemicals were weighed accurately in electronic weighing machine. All the stock solutions were poured in to well stoppered sterilized bottles and preserved in a refrigerator at $4^{\circ} \mathrm{C}$. Specific quantity of the stock solutions and growth regulators were pipetted on to a little beaker. Required source, other organic supplements and complex additives (optional) were added. The final volume was made up with distilled water and the $\mathrm{pH}$ was adjusted to 5.8 with either $1 \mathrm{~N} \mathrm{NaOH}$ or $\mathrm{HCl}$ using a $\mathrm{pH}$ meter (ELICO).

To the above said media, $0.8 \%$ agar (extra pure gelling point $32-35^{\circ} \mathrm{C}$, Hi media, Bombay) was added, melted in a water bath and the medium was dispensed into culture bottles. The bottles after covering were autoclaved at $1.06 \mathrm{~kg}$ pressure $/ \mathrm{sq} \mathrm{cm}$ 
for about $20 \mathrm{~min}$ at $121^{\circ} \mathrm{C}$. The autoclaved medium in the culture bottles were allowed to cool. The inoculation was done after 5 days to ensure that the bottles were free from contamination.

Table 1. Composition of Gamborg's (1968) medium

\begin{tabular}{|c|c|c|}
\hline S. no. & Component & $\mathrm{mg} / \mathrm{l}$ \\
\hline \multicolumn{3}{|c|}{ MAJOR SALTS } \\
\hline 1 & $\mathrm{Na}_{2} \mathrm{HPO}_{4} 2 \mathrm{H}_{2} \mathrm{O}$ & 150 \\
\hline 2 & $\mathrm{KNO}_{3}$ & 250 \\
\hline 3 & $\mathrm{CaCl}_{2} .2 \mathrm{H}_{2} \mathrm{O}$ & 150 \\
\hline 4 & $\mathrm{MgSO}_{4 .} 7 \mathrm{H}_{2} \mathrm{O}$ & 250 \\
\hline 5 & $\left(\mathrm{NH}_{4}\right)_{2} \mathrm{SO}_{4}$ & 134 \\
\hline \multicolumn{3}{|c|}{ MINOR SALTS } \\
\hline 6 & $\mathrm{KI}$ & 0.75 \\
\hline 7 & $\mathrm{H}_{3} \mathrm{BO}_{3}$ & 3 \\
\hline 8 & $\mathrm{MnSO}_{4} .4 \mathrm{H}_{2} \mathrm{O}$ & 10 \\
\hline 9 & $\mathrm{ZnSO}_{4} .7 \mathrm{H}_{2} \mathrm{O}$ & 2 \\
\hline 10 & $\mathrm{Na}_{2} \mathrm{MO}_{4} 2 \mathrm{H}_{2} \mathrm{O}$ & 0.25 \\
\hline 11 & $\mathrm{CuSO}_{4 .} 5 \mathrm{H}_{2} \mathrm{O}$ & 0.025 \\
\hline 12 & $\mathrm{CoCl}_{2} \cdot 6 \mathrm{H}_{2} \mathrm{O}$ & 0.025 \\
\hline 13 & $\mathrm{C}_{10} \mathrm{H}_{12} \mathrm{~N}_{2} \mathrm{O}_{8} \mathrm{Fe} \mathrm{Na}$ & 43 \\
\hline \multicolumn{3}{|c|}{ VITAMINS AND ORGANICS } \\
\hline 14 & Meso-Inositol & 100 \\
\hline 15 & Nicotinic acid & 100 \\
\hline 16 & Pyridoxine $\mathrm{HCl}$ & 100 \\
\hline 17 & Thiamine $\mathrm{HCl}$ & 100 \\
\hline 18 & Cystine & 10 \\
\hline 19 & Sucrose & 20 \\
\hline 20 & Agar & 8 \\
\hline 21 & $\mathrm{Ph}$ & 5.8 \\
\hline
\end{tabular}

\subsection{Growth regulator and it's preparation}

Growth regulator like gibberillic acid was used in the experiments.

\subsection{Preparation of Gibberillic acid $\left(G A_{3}\right)$}

The stock solution was prepared by dissolving $10 \mathrm{mg}$ of $\mathrm{GA}_{3}$ in $1 \mathrm{~mL}$ of ethanol and the volume was made up to $100 \mathrm{~mL}$ with sterile distilled water. This was used in two different concentrations (0.5 and $1.0 \mathrm{mg} / \mathrm{L})$.

\subsection{Culture conditions}

The cultures were maintained at $25 \pm 2 \circ \mathrm{C}$ under a $16 \mathrm{hr}$ photoperiod of $50-60 \mu \mathrm{mol}$ flux intensity provided by cool white fluorescent tubes.

\subsection{In vitro seed germination}

Half $B_{5}$ (half strength Gamborg's medium) medium was used for seed germination.

\subsection{Artificial seed preparation}

For encapsulation purpose 5\% sodium alginate and $100 \mathrm{mM}$ calcium chloride (w/v) were prepared using sterile distilled water.

\subsection{Formation of beads}

The protocorms were transferred to the sodium alginate solution. The protocorms along with sodium alginate matrix were dropped into a solution of calcium chloride and maintained for atleast 15 min to polymerize the beads. (When sodium alginate drops come in contact with calcium chloride solution surface complexation begins and form round beads). The beads were recovered by discarding the calcium chloride solution and later washed twice with sterile distilled water.

\subsection{Culture medium and conditions}

The encapsulated protocorms were cultured on a half strength $B_{5}$ medium supplemented with 1.0 $\mathrm{mg} / \mathrm{L}$ of $\mathrm{GA}_{3}$. All cultures were maintained in the culture room at $25 \pm 2^{\circ} \mathrm{C}$ under a $16 \mathrm{hr}$ photoperiod.

\section{RESULTS AND DISCUSSION}

Orchids are faced with habitat destruction pressures due to extensive collections in the past. As a consequence the species has become rare and is restricted to very narrow pockets in its natural habitats (Kaur and Bhutani 2009). Thus to conserve this orchid from extinction and to increase the population size, plant tissue culture and micropropagation can play a significant role (Wochok, 1981). The increasing demand, and export values of orchids each year is driving the expansion of orchid growing areas (Kasikorn Research Center, 2008). A Significant number of identical clones can be raised from a single leaf through direct or callus mediated organogenesis (Arditti, 1977). Many reports have been made in growing the orchid pods in full strength MS medium and Knudson's medium. So the present study mainly focused on growing the seeds on half $B_{5}$ medium and to prepare synthetic seeds from protocorms.

The seeds of orchids produced in large numbers in each capsule are highly fragile and possess virtually no stored food material and endosperm. The epiphytic orchid V.testace has poor seed germination under natural condition. Seeds were cultured on Knudson's C medium, enriched with various concentrations of organic additives and plant growth regulators to study asymbiotic germination, seedling development and optimization of the cultural requirements (Mukhopadhyay and Roy, 1994).

The matured capsules are brown and thick in nature. The surface sterilized matured pods were opened under aseptic condition and the seeds were deposited on half strength $\mathrm{B}_{5}$ (Half Strength Gamborg's Medium) medium supplemented with 
$1.0 \mathrm{mg} / \mathrm{L} \mathrm{GA}_{3}$. After 45 days of inoculation the seeds started germinating. Further the germinated seeds were allowed to grow in the same medium up to 90 days. Protocorm like bodies (PLB's) were formed after 90 days of culture (Plate-1). Seed germination and development of three Vanda hybrids were reported by Timothy Johnson (2007). Six asymbiotic orchid seed germination media were examined for their effectiveness in promoting germination and subsequent protocorm development of Bletia purpurea seeds was reported by Malmgren (1996).

\section{Plate-1}

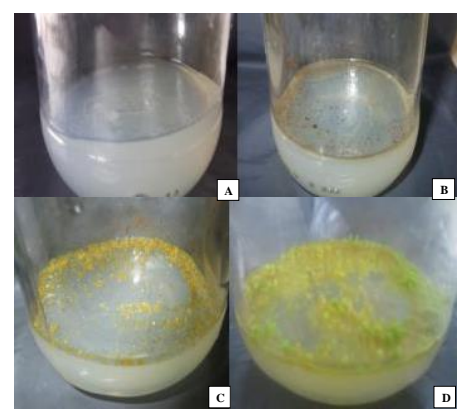

A. Inoculated orchid pod

B. Changes in colour after 30 days of inoculation

C. Formation of protocorms after 45 days of inoculation

D. Well grown protocorms after 60 days of inoculation

Further the fully developed protocorm like bodies (PLB's) were separated from the medium and subjected to artificial seed preparation. The mature protocorm like bodies (PLB's) were collected and mixed with $5 \%$ sodium alginate and dropped into $100 \mathrm{mM}$ of calcium chloride solution to form beads of synthetic seeds. Subsequently the beads were washed with sterile double distilled water and inoculated on half strength $\mathrm{B}_{5}$ medium supplemented with $1.0 \mathrm{mg} / \mathrm{L} \quad \mathrm{GA}_{3}$ (Plate- 2 ). The seedling development of Onicidium $s p$. was best on the MS medium supplemented with $2 \mathrm{mg} / \mathrm{l}$ BA (Sharma, 1991). Several valuable species of Dendrobium have been reported to be propagated through asymbiotic germination via immature seeds (Vij et al., 1981).

Plate-2

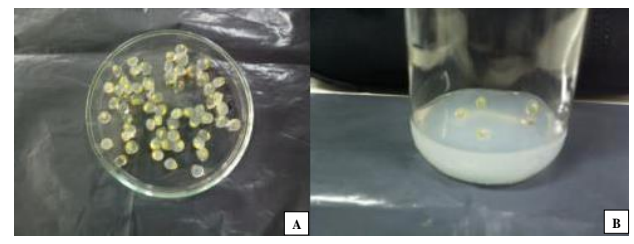

A. Prepared synthetic seed

B. Synthetic seed inoculated on half $B_{5}+1 \mathrm{mg} / \mathrm{LGA}$

\section{CONCLUSION}

The findings of present study suggested that the asymbiotic seed germination was best on half $\mathrm{B}_{5}$ medium supplemented with $1.0 \mathrm{mg} / \mathrm{L} \mathrm{GA}_{3}$ and $5 \%$ sodium alginate and $100 \mathrm{mM}$ of calcium chloride was suitable for artificial seed preparation.

\section{REFERENCES}

Arditti, J. (1977). Clonal propagation of orchids by means of tissue culture: A manual In: Arditti, J. (ed.), Orchid Biology: Reviews and Perspectives. 1: 203-293.

Chauhan, N.S.(1990) Medicinal orchids of Himachal Pradesh. Journal of Orchid society india. 4: 99-105.

Kasikorn Research Centre. 2008. Thai Orchids-Bright prospect in World Market.

Kaur, S. and Bhutani, K.K. (2009). In vitro propagation of Vanda testacea (Lindl.) Reichb.f.- A Rare Orchid of High Medicinal Value. Plant Tissue Culture and Biotechnology. 19:1-7.

Wochok, Z.S. (1981). The role of tissue culture in preserving threatened and endangered plant species. Biological Conservation. 20: 83-89.

Malmgren,S.(1996). Orchid propagation: theory and practice. in: Allen.C(Ed) north American native terrestrial orchids propagation and production. Proceeding of the north American native terrestrial orchid conference. 63-71.

Mukhopadhyay, K. and Roy, S.C. (1994). In vitro induction of 'runner'- $A$ quick method of micropropagation in orchid Science of Horticulture. 56: 331- 337.

Santh Rani Thakur and Swapna Pokkula. (2013) Ameliorative effects of vanda testacea in sciatic nerve transaction-Induced neuropathy in rats. International Journal of Pharmacuetical and Biosciences. 4: 271-284.

Sharma , N., Chandel, K.P.S., and Srivastava, V.K . (1991). In vitro propagation of Coleus forkohlii Briq. A threatened medicinal plant. Plant Cell Replication. 10: 67-70.

Soumi neha, Tustu mondal and Nirmalya Banerjie. (2013). Research article asymbiotic seed germination and seedling development of vanda testacea (LINOL) REICHB.F.: An in vitro approach for optimization of cultural requirements for medicinally important rare orchid. Department of botany, visva-bharathi university. Academic journals.

Timothy and Johnson. (2007). Asymbiotic seed germination of vanda: In vitro germination and development of three hybrids. University offlorida.

Vij, S.P., Sood, A., and Plaha,k.k. (1981). In vitro seed germination of some epiphytic orchids. In: Verma, s.c. (ed). Contemporary trends in plant sciences. New Delhi: Kalyani publishers. 473-481. 